\title{
Case Reaport: \\ Application of Negative Reinforcement and Reward Technique to Reduce Behavior of Collecting Goods in a Patient With Schizophrenia
}

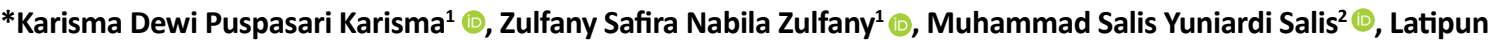 \\ Latipun ${ }^{2}$ (B)
}

1. Department of Professional Psychology, School of Psychology Education, University of Muhammadiyah Malang, Indonesia.

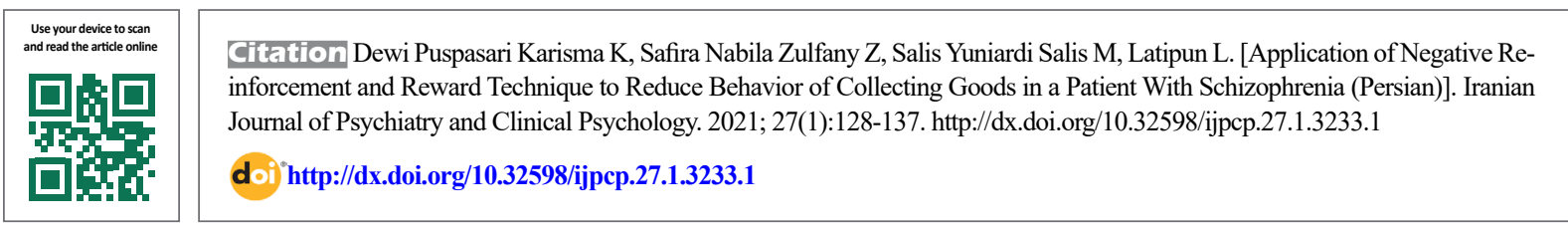

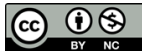

Received: 03 Oct 2019

Accepted: 29 Aug 2020

Available Online: 01 Apr 2021

Key words:

Negative reinforce-

ment, Reward,

Behavior therapy,

Schizophrenia

\section{A B S T R A C T}

Our subject is a 55-year-old man and a former civil servant. He claimed to have seen someone who others could not see. He believed that he is an important person. He had strange behavior such as separating himself from others, speaking and laughing alone, and collecting rubbish. Based on the assessment through observation, interviews, and psychological tests, the subject was diagnosed with schizophrenia and behavioral problems such as collect things. The subject's behavior appears because he feels pleasure after collecting goods. He did not do other activities that make him feel good; thus, the behavior was repeated. The intervention aims to reduce the frequency of collecting things through negative reinforcement and rewards techniques. The intervention eventually suppressed the behavior of collecting things carried out by the subject gradually.

\section{Extended Abstract}

\section{Introduction}

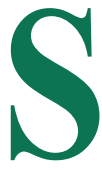

chizophrenia is a persistent psychotic disorder where the affected person has characteristics, such as disordered thinking, emotions, perceptions, and behavior. Also, acute episodes of schizophrenia are characterized by delusions, hallucinations, illogical thoughts, incoherent speech, and strange behavior [1].

The symptoms of schizophrenia can be explained through the theory of the diathesis-stress model. This model combines biological, psychosocial, and environmental factors that specifically affect a person to cause the development of symptoms of schizophrenia [2].

People with schizophrenia have problems in executing their functional abilities. Individuals with schizophrenia often have strange or unnatural behavioral habits. One of the behaviors is collecting goods. Our patient was interested in collecting goods, especially second-hand, and useless goods such as old newspapers, cigarettes, and food wrappers. Then, he stored goods in his pants and room. This behavior certainly disturbs him and others around him. This behavior is usually based on the pleasure in carrying out such strange behavior. He did not feel pleasure when doing other activities, so that odd behavior tended to be repeated.

* Corresponding Author:

Karisma Dewi Puspasari Karisma

Address: Department of Professional Psychology, School of Psychology Education, University of Muhammadiyah Malang, Indonesia.

Tel: +26 (341) 562124

E-mail: krsmdw@gmail.com 
Tabel. Content of Sessions

\begin{tabular}{|c|c|c|}
\hline Sessions & & Content of Sessions \\
\hline 1 & $\begin{array}{l}\text { Determine the targeted } \\
\text { behavior }\end{array}$ & $\begin{array}{l}\text { In this session, the behavior targeted by the intervention is defined as reducing the frequency of } \\
\text { collecting second-hand and useless goods by the subject. }\end{array}$ \\
\hline 2 & $\begin{array}{l}\text { Determining negative re- } \\
\text { inforcement and reward }\end{array}$ & $\begin{array}{l}\text { This session aims to set negative reinforcer versus reward favored by the subject. The reward was } \\
\text { telling about psychology as a reinforcement of the subject's new behavior. Also, the negative rein- } \\
\text { forcement was the prohibition to drink coffee. }\end{array}$ \\
\hline 3 & Implementation phase & $\begin{array}{l}\text { At this stage, the techniques of negative and positive reinforcement were applied during five meet- } \\
\text { ings. Every day, the subject has } 4 \text { targets for not collecting goods. If the subject were still collecting } \\
\text { goods from the four targets, the subject would get a negative reinforcement, which was depriving } \\
\text { him from drinking coffee the next day. If the subject's bad behavior decreased from the } 4 \text { targets, } \\
\text { then the subject would get a reward and was told a story about psychology. }\end{array}$ \\
\hline 4 & Evaluation & $\begin{array}{l}\text { At this stage, the intervention carried out for } 5 \text { days is evaluated as to whether the target set had } \\
\text { been met. Also, obstacles that the subject went through during the intervention are evaluated. }\end{array}$ \\
\hline 5 & Stopping the program & $\begin{array}{l}\text { When the subject experiences a behavior change, the frequency of collecting the second-hand } \\
\text { and unused goods should be reduced. The subject knows that he should not collect these goods, } \\
\text { and then the intervention can be stopped. In this session, the changes in the subject's behavior } \\
\text { during the intervention are discussed, that the subject has changed for the better so that he gets } \\
\text { motivated and knows that he can always reduce the behavior of collecting things. }\end{array}$ \\
\hline
\end{tabular}

Iranian Journal of
PSYCHIATRY AND CUNICAL PSYCHOLOG

The principles of behavior can be applied to individuals with schizophrenia, where the behavior tends to be repeated because there is a feeling of pleasure. This outcome is in accordance with the principle of operant conditioning that pleasure in collecting goods is a reinforcement for the subject to repeat his behavior.

Appropriate interventions for handling this case are operant conditioning: a technique based on a learning approach involving rewarding individuals for the expected emergence of behavior [3]. If a reinforcing stimulus follows the appearance of an operant, the strength of the behavior will increase so that the behavior will become persistent [4].

Negative reinforcement is given as a consequence received by the subject if he cannot reduce the frequency of collecting goods. It aims to reduce the behavior of collecting goods carried out by the subject. In contrast, a reward reinforces a new subject's behavior if the subject can reduce the frequency of collecting rubbish.

\section{Methods}

The initial assessment was carried out to obtain information about the subject through interviews, observations, and psychological tests. Also, informed consent was obtained from the subject's family. Interviews were conducted with the subject, the subject's family, and the officer in the subject's care area.

Observations were made to observe the subject's maladaptive behavior. The Wechsler Adult Intelligence Scale
(WAIS) was implemented to determine the intelligence level of the subject. The personality tests of DAP, BAUM, HTP, and WARTEGG were performed to find out the subject's personality. Also, the Thematic Apperception Test (TAT) test was done to determine the press and needs experienced and needed by the subject. Finally, Woodworth $>\mathrm{S}$ questionnaire was introduced to determine the clinical condition of the subject.

\section{Diagnosis}

Based on the assessment, the subject was an introverted person, organized and bound by rules, and impulsive. The subject had schizophrenic tendencies, experienced hallucinations, had wrong beliefs about himself, and behaved strangely; however, he had an average level of intelligence. It can be concluded that the subject meets the criteria of the Diagnostic and Statistical Manual of Mental Disorder Fifth Edition [5] for schizophrenic disorders (295.90) with behavioral problems of collecting goods.

\section{Intervention}

Negative reinforcement is often felt like a punishment or something that is a burden on the subject, increasing desired behavior [6]. A reward is given to increase or repeat the expected behavior [7]. This intervention consisted of 5 sessions (Table 1). 


\section{Results}

The results of the interventions were evaluated based on the number of observations of the behavior of collecting goods by the subject at one meeting. The list of observed behaviors consists of four behaviors because these they are always carried out by the subject every morning.

Optimal intervention result is achieved if the subject has a total value of 0 in each day which means that the subject does not collect goods at all. But this is quite difficult for the subject because the habit of collecting goods has been made for a long time. Therefore, a gradual decrease is a significant improvement gained from the intervention process. The intervention results to reduce the behavior of collecting used and useless goods by the subject can be seen in Figure 1. Based on Figure 1, there is a decrease in the behavior of collecting goods.

The subject has the initiative to abandon collecting goods in some situations after implementing the fifth session. So, this outcome is considered as the subject's progress during the intervention, and the intervention can be ended even if the subject has not gotten the maximum results or get a score of 0 .

At first, the subject was angry and did not want to follow the intervention because it interfered with his habits. But after receiving the proper explanation, he followed the intervention at the next meeting.

After the intervention, the subject could resist collecting cigarettes and rubbish. This result can be interpreted as the subject began to form the new behavior of no longer collecting the goods. Now, the subject feels that by not collecting those rubbish, his body has become cleaner than before.
One month after the intervention, the subject can hold his behavior of not collecting cigarettes and rubbish. However, collecting coffee packs and newspapers was still done by the subject because he still considers them valuable objects.

\section{Discussion and Conclusion}

Applying positive and negative reinforcement techniques can reduce the behavior of collecting goods carried out by the subject. By using operant conditioning, the subject's behavior can be conditioned. Negative reinforcement given to the subject is something that is not liked by the subject. The undesirable things will reduce the probability of the occurrence of undesirable behavior. This fact is supported by research that states that schizophrenic patients can respond to negative reinforcement, which is what they dislike [8]. Giving rewards as a positive reinforcer and negative reinforcement has a large influence on the behavior of schizophrenic patients so that by providing rewards and punishment, the behavior of schizophrenic patients can be changed [9].

Reward or punishment given to the subject can make the subject happy and motivated not to collect goods. This fact is supported by research that schizophrenic patients can feel positive emotions when confronted with stimuli that make them remember pleasant things [10], which in this case is telling about psychology.

Giving rewards in the form of stories about psychology can also be categorized as social interaction. Social interactions occur between therapists and schizophrenic patients, making patients feel happy [11]. They also feel to be more valuable persons. Through the interactions, an individual with schizophrenia will not feel too different from others. This issue can encourage their willingness to follow the treatment [12].

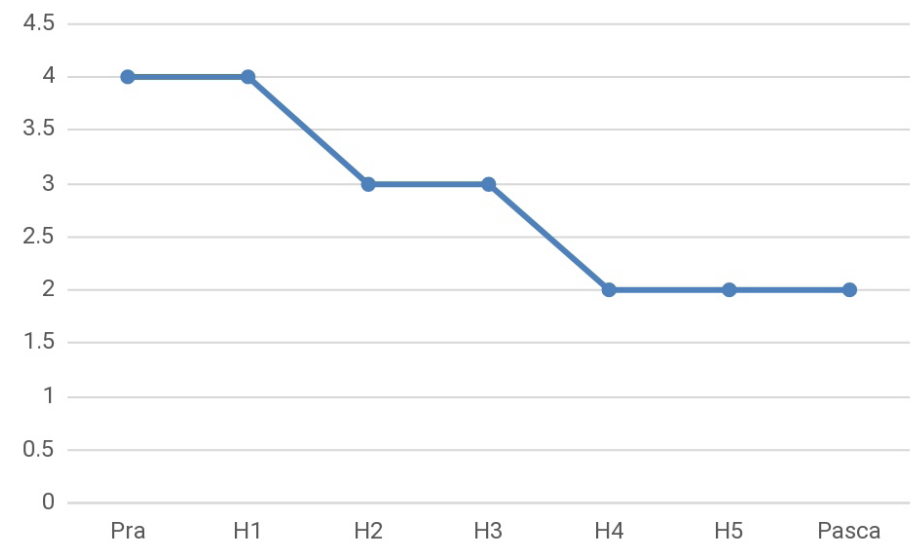

Figure 1. Behavior progress 
Interventions using a behavioral approach through punishment and reward techniques can reduce the subject's maladaptive behavior. Based on the evaluation results of each session on four behavior targets to collect goods, the subject changed gradually. The main change in the subject after the intervention was that he no longer collected used goods and cigarettes from the streets. This gradual change was judged as the success of the intervention process even though the subject could not collect goods at all.

Suggestions for further researchers are to conduct studies in a more extended period to see changes in the subject's behavior and giving psychoeducational to the people around the subject about preventing relapse in schizophrenia patients. Especially, the researchers should pay attention to routine drug administration and provide social support to provide activities that can make the subject feel happy and valuable.

\section{Ethical Considerations}

\section{Compliance with ethical guidelines}

This study was approved by The Ethics Committee of the Master of Professional Psychology, University of Muhammadiyah Malang.

\section{Funding}

This research did not receive any grant from funding agencies in the public, commercial, or non-profit sectors.

\section{Authors contributions}

All authors equally contributed to preparing this article.

\section{Conflicts of interest}

The author declared no conflict of interests. 
This Page Intentionally Left Blank 

استفاده از تكنيك تثويت و ياداش منفى براى كاهش رفتار جمع آورى الشيا در مبتايان به اسكيزووفرنى

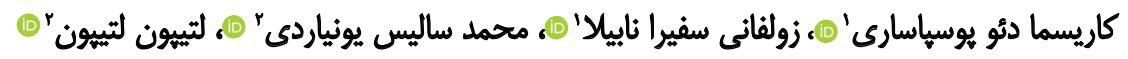
1. كروه روانشناسى حرفه اي، دانشكده آموزش روانشئاسى، دانشَّاه محمديه مالنك، اندونزى.

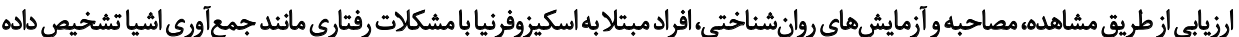

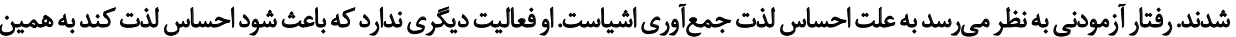

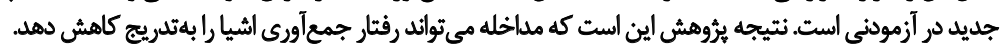

كليدواروها:

تقويت منفى، ياداش،

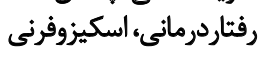

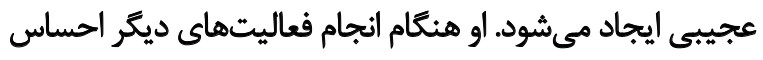

dales

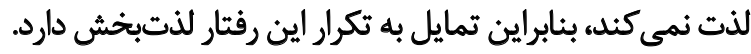

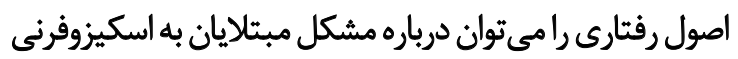

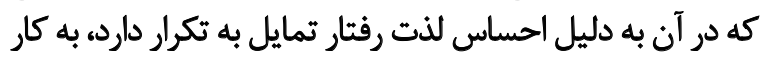

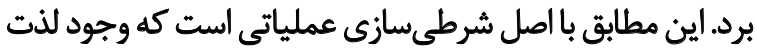

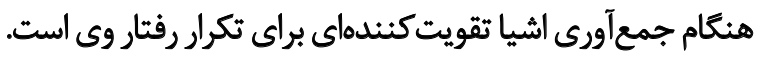

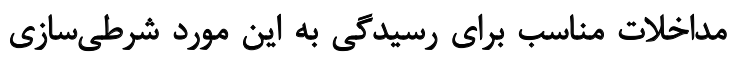

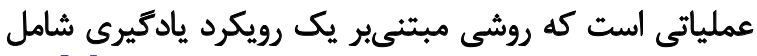

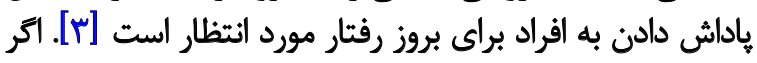

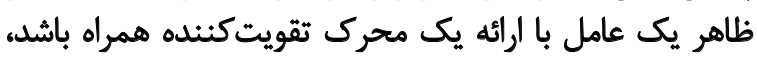

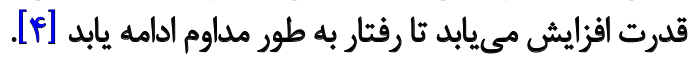

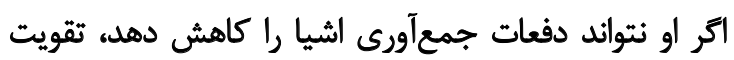

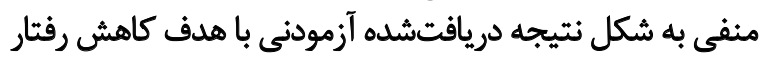

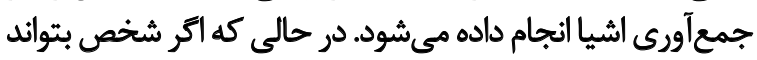

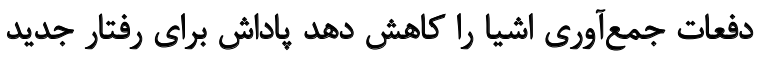
آزمودنى تقويت مى جـود.

روشُ

اريابى براى به دست آوردن اطلاعات درباره آزمودنى از اسكيزوفرنى نوعى اختلال روان بريشى مداوم است كه فرد مبتلا

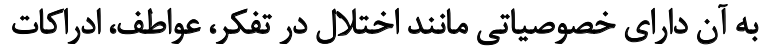

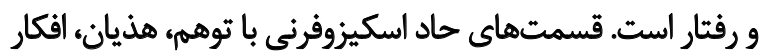

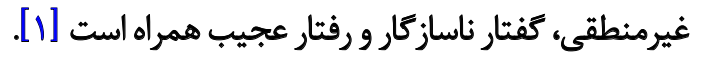

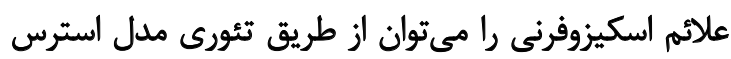

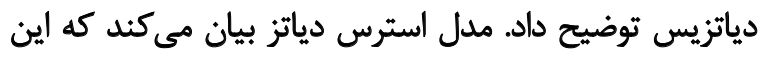

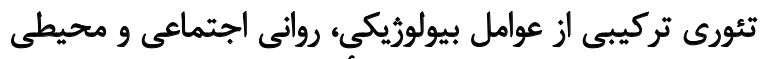

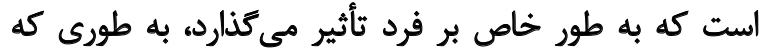

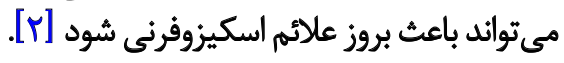

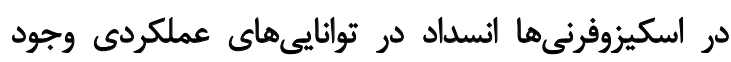

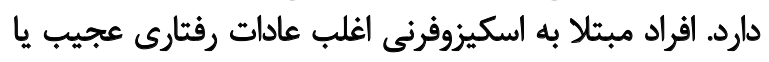
غيرطبيعى دارند. يكى از اين رفتارها جمعآورى آشيت اشياست. آزمودني اين يُروهش دوست دارد اشيا را جمعآورى كندي

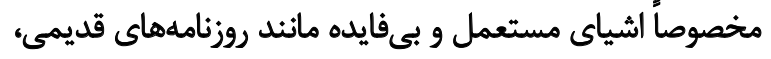

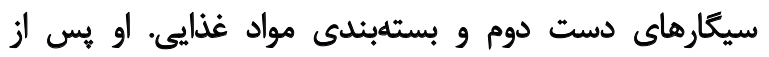

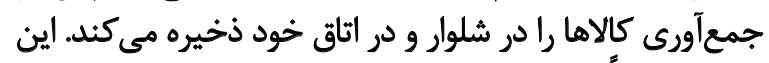

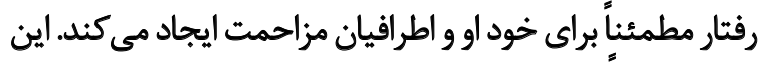

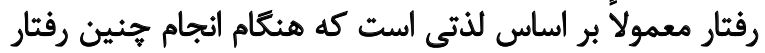


جدول ا. محتواى جلسات

هحتواى جلسات

در اين جلسه از مداخله رفتار هدفمند براي كاهش دفعات جمعآورى اشيا اسثفاده شدو فرد در ابثلا آن را بيىفايده تعريف مىكثد.

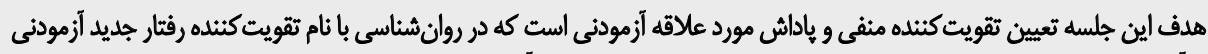

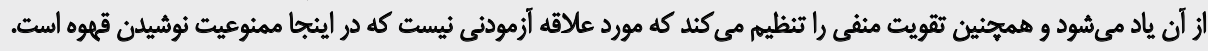

\section{ا تعيين رفتار هدفمند

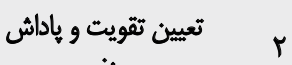 منفى}

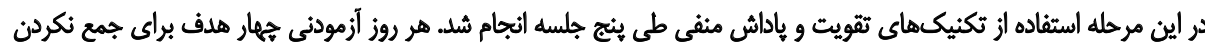

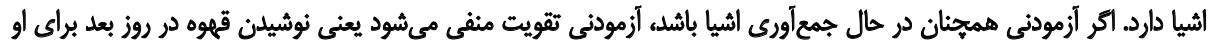

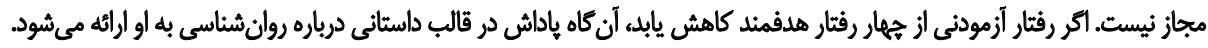

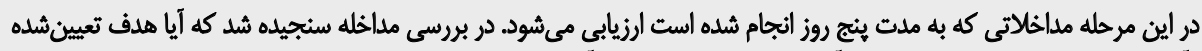

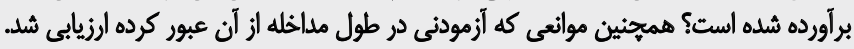
ا ازيابيى r

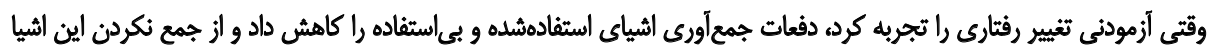

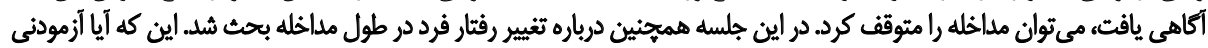

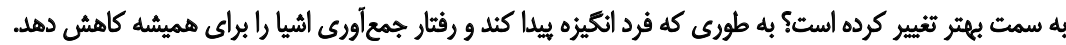

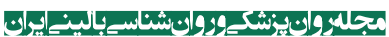

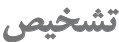

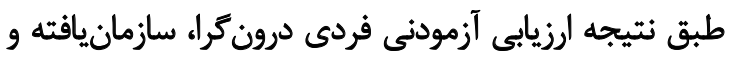

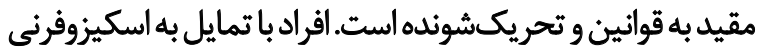

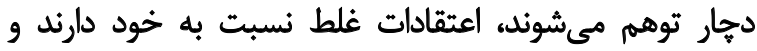

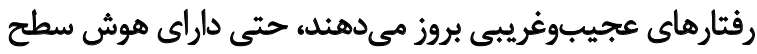

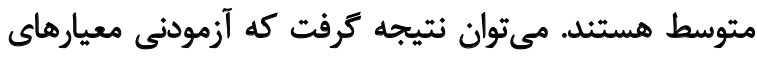

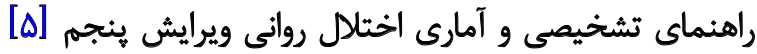

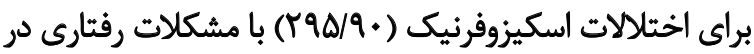

$$
\text { جمعآورى اشيا را داراست. }
$$

مليأlid

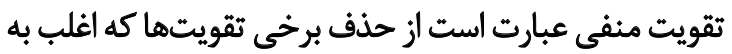

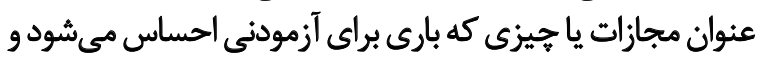

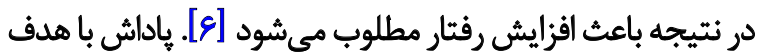

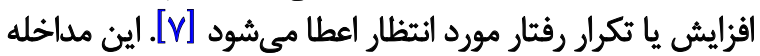

طريق مصاحبه، مشاهدات و آزمايشهاى روانشناسى انجام شده

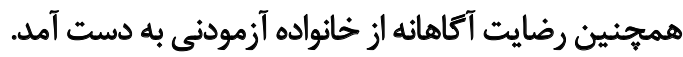

$$
\text { مراحل كار به صورت زير است: }
$$

ا. مصاحبه با خانواده آزمودنى و همجنين كارمند حوزه

$$
\text { مراقبت از آزمودنى؛ بأخ }
$$

r. مشاهدات براى سنجش رفتار ناسازگًار آزمودنى؛

$$
\text { WAIS براى تعيين سطح هوش آزمودنى؛ }
$$

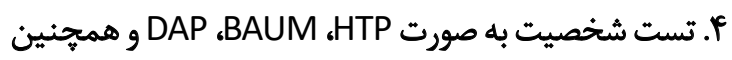

WARTEGG براى يى بردن به شخصيت آزمودنى؛

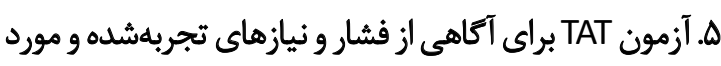

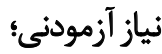

و. يرسشنامه وودورث براى تعيين وضعيت بالينى آزمودنى.

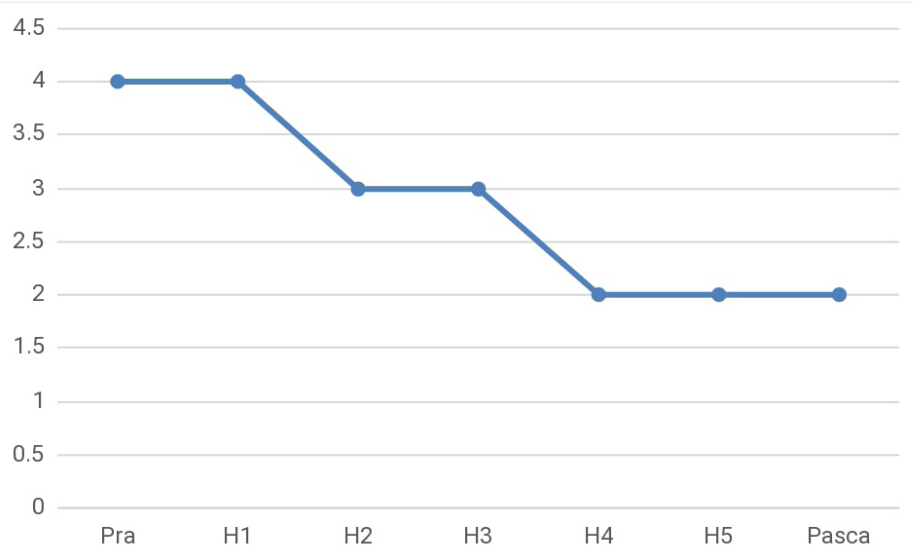


مهى كند بيماران اسكيزوفرنى مي توانند به ارائه تقويت منفى كه

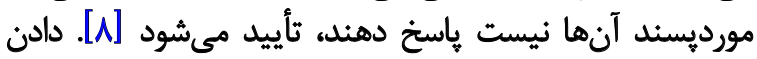

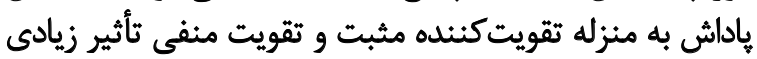

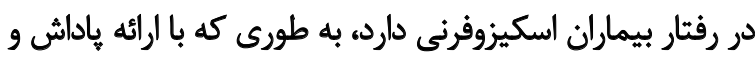

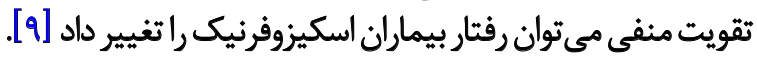

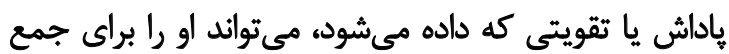

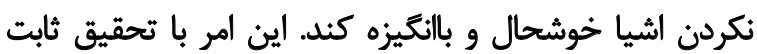

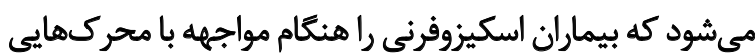

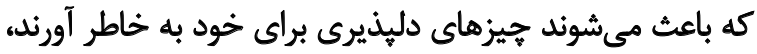

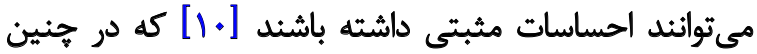

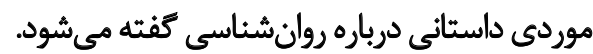

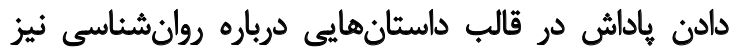

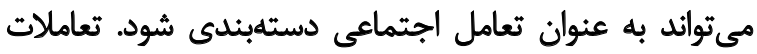

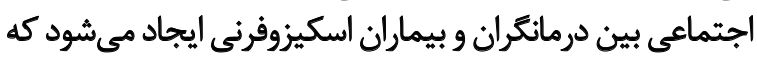

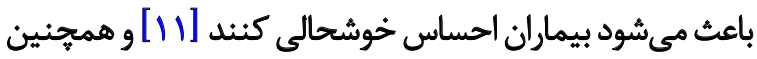

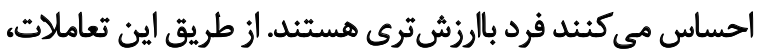

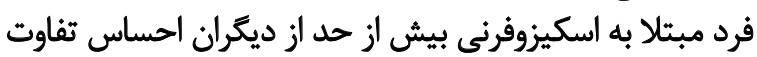

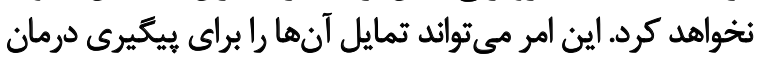

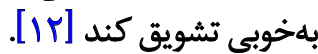

\section{تثيجه}

مداخلات با استفاده از رويكرد رفتارى از طريق تقويت منفى رئي

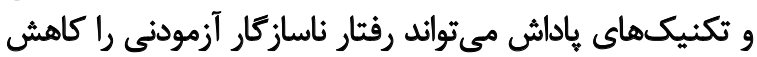

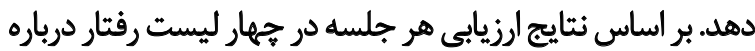

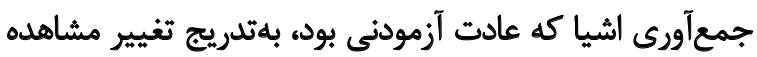

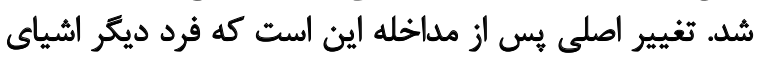

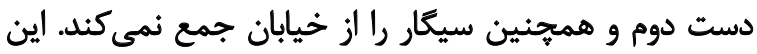

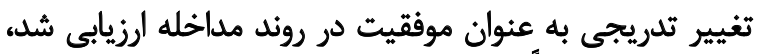

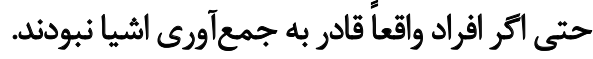

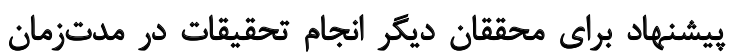

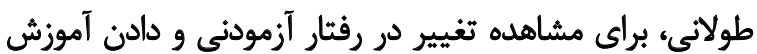

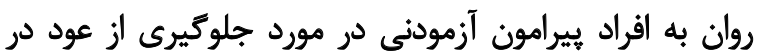

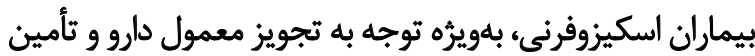

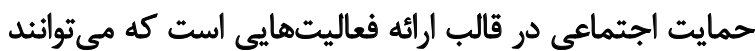

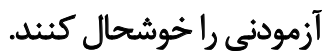

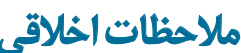

\section{يبروى از اصول اخلاق يروهش}

اين مطالعه توسط كميته اخلاق استاد روانشناسى حرفهاي، دانشكاه محمديه ملنك تأييد شده است.
شامل بنج جلسه بود (جدول شماره ().

يافتهها

نتايج مداخلات بر اساس تعداد مشاهدات رفتار جمع آورى اشيا

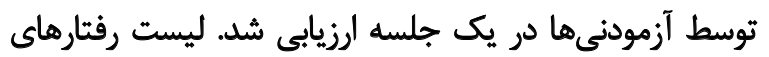

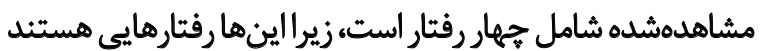
كه هميشه هر روز صبح آزمودنى انجام مى دادي.

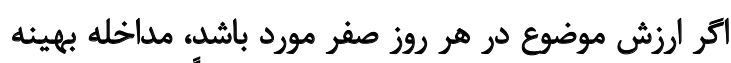

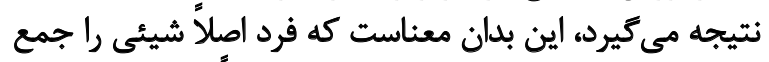

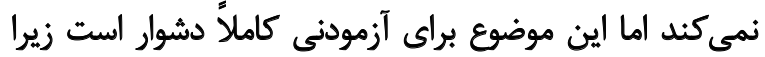

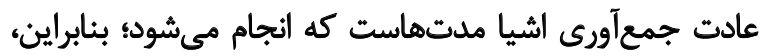

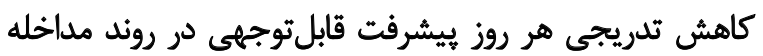

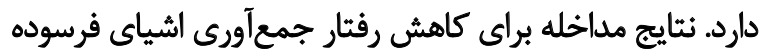

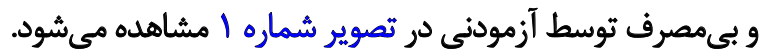

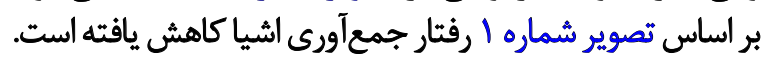

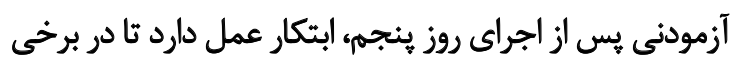

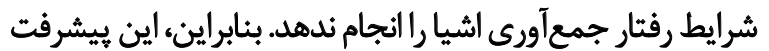

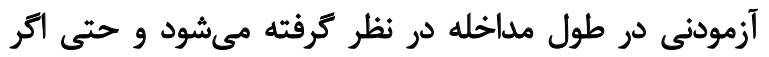

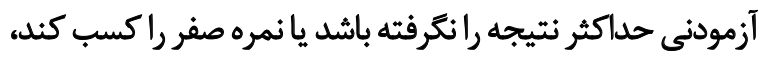
مي توان مداخله را إيايان داد.

در آغاز مداخله، آزمودنى عصبانى بود و نمى خواست مداخدانه

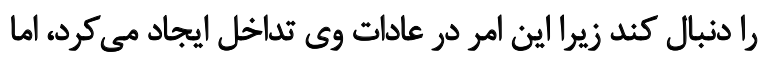

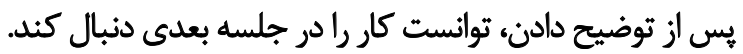
يس از مداخله، آزمودنىها مى توانند در برابر جمع آورى سيكار

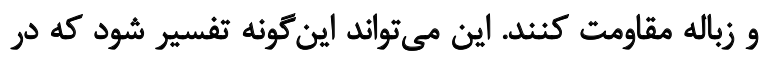

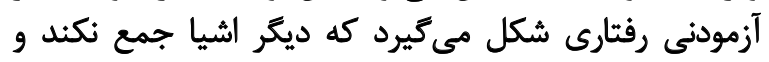

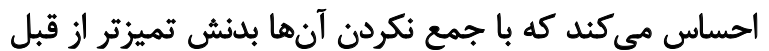

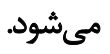

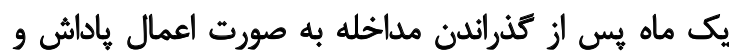

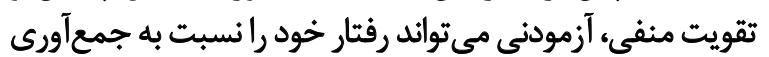

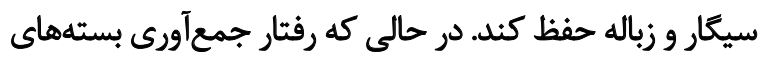

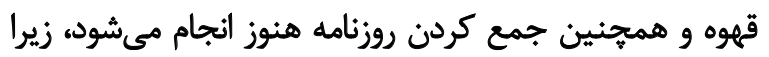

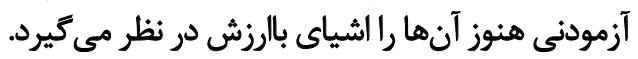

بحث

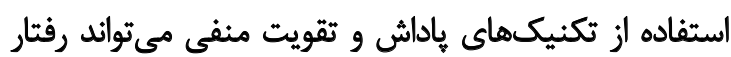

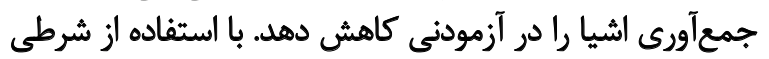

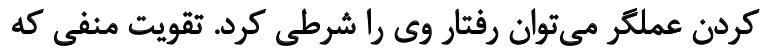

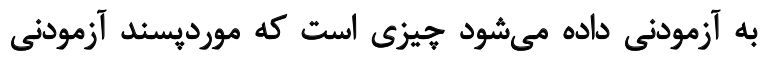

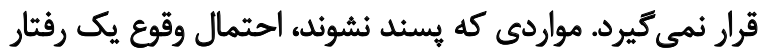

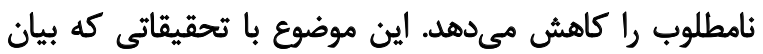




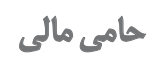

اين تحقيق هيج كونه كمك مالى از سازمان هاى تأمين مالى در

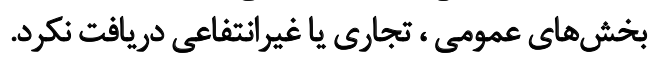

$$
\text { مشار كث نويسندكان }
$$

نويسندكان به يك اندازه در نتارش مقاله مشاركت داشتهاند.

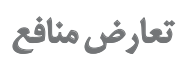

بنابر اعلام نويسندكان اين مقاله هيج تعارض منافعى ندارد. 


\section{References}

[1] Nevid JS, Rathus SA, Greene BS. Abnormal psychology in a changing world. $10^{\text {th }}$ ed. Upper Saddle River, NJ: Pearson; 2017. https://www.pearsonhighered.com/assets/preface $/ 0 / 1 / 3 / 5 / 0135821770 . p d f$

[2] Kaplan HI, Sadock BJ, Grebb JA. Kaplan and Sadock's synopsis of psychiatry: Behavioral sciences, clinical psychiatry. Williams \& Wilkins Co.; 1994. https://www.psychiatrist.com/readpdf/11671/

[3] Corey G. Theory and practice of counseling and psychotherapy. $8^{\text {th }}$ ed. Belmont, USA: Thomson Brooks/Cole; 2009. https:// books.google.com/books?hl=en\&lr=\&id=2YcJAAAAQBAJ\&oi=

[4] Hergenhahn BR, Olson MH. An introduction to theories of personality, $5^{\text {th }}$ ed. Upper Saddle River, NJ: Prentice-Hall, Inc.; 1999. https:// psycnet.apa.org/record/1998-08082-000

[5] American Psychological Association. Diagnostic and statistical manual of mental disorders, $5^{\text {th }}$ ed. Washington, DC.: American Psychological Association; 2013. https://books.google.com/ books?id=

[6] Ormrod JE, Anderman EM, Anderman LH. Educational psychology: Developing learners. Upper Saddle River, NJ: Pearson; 2008. https://www.pearson.com/us/higher-education/program/Ormrod-Educational-Psychology-Developing-Learners6th-Edition/PGM2815465.html

[7] Pomerantz AM. Clinical psychology: Science, practice, and culture. New York: Sage Publications; 2016. https://books. google.com/books/about/Clinical_Psychology.html?id= $\mathrm{I} 6 \mathrm{HzWp} 9 \mathrm{XKloC} \&$ printsec $=$ frontcover\&source $=\mathrm{kp} \_$read button\# $\mathrm{v}=$ onepage $\& \mathrm{q} \& \mathrm{f}=$ false

[8] Cheng GLF, Tang JCY, Li FWS, Lau EYY, Lee TMC. Schizophrenia and risk-taking: Impaired reward but preserved punishment processing. Schizophrenia Research. 2012; 136(1-3):122-7. [DOI:10.1016/j.schres.2012.01.002] [PMID]

[9] Dowd EC, Barch DM. Pavlovian reward prediction and receipt in schizophrenia: Relationship to anhedonia. PLoS One. 2012; 7(5):e35622. [DOI:10.1371/journal.pone.0035622] [PMID] [PMCID]

[10] Gold JM, Waltz JA, Prentice KJ, Morris SE, Heerey EA. Reward processing in schizophrenia: A deficit in the representation of value. Schizophrenia Bulletin. 2008; 34(5):835-47. [DOI:10.1093/ schbul/sbn068] [PMID] [PMCID]

[11] Chen F, Greenberg JS. A positive aspect of caregiving: The influence of social support on caregiving gains for family members of relatives with schizophrenia. Community Mental Health Journal. 2004; 40(5):423-35. [DOI:10.1023/B:COMH.0000040656.89143.82] [PMID]

[12] Yaseen M, Jokerst T, Faiz Z. Observed social support and willingness for the treatment of patients with schizophrenia. Psychology Research and Behavior Management. 2020; 13:193-201. [DOI:10.2147/PRBM.S243722] [PMID] [PMCID] 